\title{
PREVIDÊNCIA COMPLEMENTAR: UM ESTUDO COM A POPULAÇÃO DO SUDOESTE DO PARANÁ
}

\author{
Gabriela Venzon ${ }^{1}$ \\ Edson Santos Melo ${ }^{2}$
}

\begin{abstract}
Resumo: Incertezas quanto às condições financeiras pessoais no período pós-laboral têm assumido importância cada vez maior dado todo o contexto previdenciário nacional. Diante disso, esse artigo tem por objetivo analisar o comportamento dos investimentos em previdência complementar da população residente na mesorregião Sudoeste do Paraná, considerando o ano de 2019 como período de análise. Para tanto, realizou-se um levantamento, viabilizado por um questionário aplicado a 402 entrevistados. Os resultados revelaram que a população pesquisada acredita não estar assegurada pela Previdência Social. No entanto, apenas uma parcela mínima dos entrevistados realizava outras aplicações visando se resguardarem financeiramente no futuro, como a previdência complementar. Contudo, é grande o percentual de pessoas que demonstraram não conhecer algumas informações básicas do produto. Assim, concluiu-se que se necessitam maiores investimentos em educação previdenciária para que as pessoas estejam aptas a tomarem as melhores decisões financeiras sobre suas aposentadorias.
\end{abstract}

Palavras-chave: Aposentadoria. Educação previdenciária. Previdência complementar. Sudoeste do Paraná.

\section{SUPPLEMENTARY PENSION: A STUDY WITH THE POPULATION OF THE SOUTHWEST OF PARANÁ}

\begin{abstract}
Uncertainties regarding personal financial conditions in the post-employment period have become increasingly important given the entire national social security context. In view of this, this article aimed to analyze the behavior of supplementary pension investments of the population living in the southwestern mesoregion of Paraná, considering 2019 as the analysis period. Therefore, a survey was carried out, made possible by a questionnaire applied to 402 interviewees. The results revealed that the researched population believes they are not insured by Social Security. However, only a minimal portion of the interviewees made other investments in order to protect themselves financially in the future, such as supplementary social security. However, a large percentage of people have demonstrated that they do not know some basic information about the product. Thus, it was concluded that greater investments in social security education are needed so that people are able to make the best financial decisions about their pensions.
\end{abstract}

Key-words: Retirement. Social security education. Supplementary pension. Southwest Paraná.

\section{Introdução}

Com o intuito de promover o bem-estar e a justiça social, a Constituição Federal de 1988, em seu artigo 194, estabeleceu que "a seguridade social compreende um conjunto integrado de ações de iniciativa dos poderes públicos e da sociedade, destinadas a assegurar os direitos relativos à saúde, à previdência e à assistência social”. Para tanto, ficou resguardada ao poder público a

\footnotetext{
${ }^{1}$ Bacharela em Ciências Econômicas pela Universidade Estadual do Oeste do Paraná, Campus de Francisco Beltrão. Email: gabrielavenzon@outlook.com

${ }^{2}$ Mestre em Economia Aplicada pela Universidade Federal de Viçosa. Doutorando em Desenvolvimento Regional pela Universidade Tecnológica Federal do Paraná. Professor da Universidade Estadual do Oeste do Paraná, Campus de Francisco Beltrão. Email: edson.melo@unioeste.br
} 
competência de assegurar a universalidade da cobertura, uniformidade e equivalência dos benefícios, equidade na forma de participação, entre outros.

Porém, o Brasil passou por significativas mudanças estruturais sociais e demográficas nas últimas décadas. Entre tais transformações, observa-se o aumento da longevidade da população combinada a uma acentuada inversão na pirâmide etária, o que, em tese, é motivo de preocupação tanto para o governo quanto para a população, visto que essa questão pode comprometer o futuro econômico do país e aprofundar as já enormes desigualdades sociais internas, objetivando, assim, ações coletivas ou individuais que sejam capazes de maximizar o bem-estar social.

Para ilustrar tal fato, apresentam-se algumas informações demográficas. Conforme dados do Instituto Brasileiro de Geografia e Estatística - IBGE (2007), a expectativa de vida da população brasileira, em 1940, era de 42,7 anos e as mulheres tinham, em média, 6,2 filhos. Já nos anos mais recentes do século XXI, a expectativa de vida está estimada em 76 anos, com o número médio de filhos de 1,77 filhos por mulher (IBGE, 2018).

O processo de envelhecimento populacional brasileiro, tende a se acelerar ainda mais nas próximas décadas. Segundo Constanzi (2018), a estimativa de variação das pessoas por faixa etária mostra uma movimentação crescente e mais intensa para as idades mais avançadas, como pessoas com 65 anos ou mais, enquanto a faixa de pessoas entre 15 a 64 anos deve verificar reduções significativas entre os anos de 2038 a 2048. Observa-se que, em 2060, o grupo etário de 15 a 64 anos será inferior ao conjunto atual, sendo que é justamente nesse grupo que se encontra a população economicamente ativa do país e, portanto, os contribuintes para a previdência social. Por outro lado, estima-se que no ano de 2060, um quarto da população brasileira deverá ter mais de 65 anos (IBGE, 2018).

Diante dessas alterações demográficas e a tendência de inversão de pirâmide etária, o sistema previdenciário demanda atenção especial, uma vez que o principal sistema vigente no país é o de repartição simples, no qual os trabalhadores ativos realizam contribuições que são direcionadas aos pagamentos dos benefícios aos aposentados. As projeções já evidenciam que, no ano de 2060, para cada 100 pessoas entre 0 e 14 anos, o país terá cerca de 206,2 idosos. Dessa maneira, há uma tendência de que a Previdência Social não possua aportes suficientes para subsidiar a massa de aposentados (BRASIL, 2018).

Segundo dados do Brasil (2019a), o Instituto Nacional de Seguro Social (INSS) concedeu mais de 35,6 milhões de benefícios ${ }^{3}$, sendo que $84,39 \%$ correspondiam apenas aos benefícios

\footnotetext{
${ }^{3}$ Considera-se o somatório dos benefícios previdenciários (aposentadorias, pensão por morte, auxílio-doença, saláriomaternidade, etc.), acidentários (aposentadorias, pensão por morte, auxílio-doença, auxílio-acidente e auxíliosuplementar) e assistenciais (Loas, rendas mensais vitalícias, etc.).
} 
previdenciários. Desses últimos, 68,31\% estavam distribuídos na área urbana. Além disso, o valor médio pago nos benefícios previdenciários foi de $\mathrm{R} \$ 1.335,69^{4}$. Destaca-se, ainda, que aproximadamente 19 milhões de beneficiários recebiam até um salário mínimo.

Todo esse cenário resulta em novas perspectivas no quadro econômico futuro, tornando-se necessário ampliar as discussões acerca do tema, pautando, principalmente, o nível de poupança e a cultura previdenciária da sociedade brasileira (ZEMIACKI, 2015). Assim, tem sido recorrente, devido ao processo de reforma de previdência proposto à sociedade brasileira, ampliar o entendimento e a discussão sobre a previdência complementar, incluindo aqui temas importantes, como educação financeira e previdenciária.

É oportuno ressaltar, também, que o Sistema Previdenciário Brasileiro está estruturado, basicamente, em um tripé, no qual se encontram estabelecidos três regimes, a saber: i) o Regime Geral de Previdência social; ii) os Regimes Próprios de Previdência dos servidores; e iii) o Regime de Previdência Complementar.

Instituído formalmente no país em 1977, o Regime de Previdência Complementar é composto pelas Entidades Abertas de Previdência Complementar (EAPC) e as Entidades Fechadas de Previdência Complementar (EFPC), as quais ofertam opções de investimentos de longo prazo à população, visando a complementação de renda em um período futuro. De acordo com Brasil (2019a), no final do ano de 2019, havia no Brasil o total de R \$ 1,99 trilhões em ativos investidos em previdência complementar, sendo que anualmente são pagos cerca de $\mathrm{R} \$ 66,8$ bilhões em benefícios, o que representa, aproximadamente, $1 \%$ do Produto Interno Bruto (PIB) do país, sendo que, desse total, 95\% são pagos pelas EFPC e 5\% são pagamentos procedentes de planos comercializados pelas EAPC. Contudo, entre os mais de 16,5 milhões de contratos de previdência complementar ativos no país, 20,3\% estão nas EFPC e os demais, 79,7\% nas EAPC.

Diante do exposto, o presente trabalho tem por objetivo analisar o comportamento dos investimentos em previdência complementar da população residente na mesorregião Sudoeste do Paraná, no ano de 2019. Pretende-se, ainda, verificar de que forma tais aplicações estão relacionadas aos níveis de educação previdenciária da população analisada.

Conforme o Instituto Paranaense de Desenvolvimento Econômico e Social (IPARDES) (2017), há uma estimativa para que, até o ano de 2040, a população paranaense siga a mesma tendência da população nacional, isso é, apresente um aumento no número de idosos e uma diminuição da população jovem. Dessa forma, é certo que tal condição também seja verificada na

\footnotetext{
${ }^{4}$ Há uma grande diferença nos valores dos benefícios pagos nas áreas urbana e rural, pois, enquanto as pessoas da área urbana receberam benefícios previdenciários no valor médio de $\mathrm{R} \$ 1.539,33$, os valores pagos na área rural ficaram na média de R \$ 896,77 (BRASIL, 2019a).
} 
mesorregião Sudoeste do Paraná. Portanto, faz-se necessária a compreensão do panorama das aplicações em previdência complementar na região, para, assim, embasar e subsidiar ações que busquem alternativas possíveis a fim de garantir a seguridade e bem-estar social para a população local.

\section{Regime de Previdência Complementar}

A previdência complementar no Brasil não é recente, havendo registro desde $1835^{5}$ de sistemas com características próximas as encontradas atualmente. Da forma como é conhecida hoje, a previdência complementar foi institucionalizada pela Lei 6.435, de 15 de julho de 1977 (BRASIL, 1977), sendo, posteriormente, regulamentada pelo Decreto $n^{\circ}$ 81.240, em 20 de janeiro de 1978 (BRASIL, 1978). Porém, a evolução do sistema de previdência complementar obteve maior ênfase no ano de 1998, após a Emenda Constitucional nº 18 (BRASIL, 1998), em que foi introduzido, no título da ordem social, o regime complementar de previdência. Porém, sua regulamentação ocorreu somente em 2001, após a edição das Leis complementares nº 108 e 109 , consequentemente, revogando a Lei $\mathrm{n}^{\circ} 6.435 / 77$. No entanto, compete distinguir que, enquanto a Lei Complementar n ${ }^{\circ} 108$ trata da relação entre a União, os Estados, o Distrito Federal e os Municípios e as respectivas EFPC, a Lei Complementar n 109, por sua vez, dispõe sobre as regras gerais do Regime de Previdência Complementar (BRASIL, 2017a).

De acordo com Ramos (2005), a Previdência Complementar foi criada com o intuito de assegurar uma maior proteção à sociedade, visando o desenvolvimento econômico e social via capitalização dos recursos, a fim de proporcionar melhorias e maior qualidade de vida aos cidadãos. No Regime de Previdência Complementar (RPC), as contribuições acumuladas ao longo dos anos são utilizadas para restituir os benefícios de aposentadorias dos participantes, ou seja, o valor que o trabalhador aplica na atualidade formará uma reserva que será usada no futuro para o pagamento de seu próprio benefício. Esse sistema é caracterizado como um Regime de Capitalização ${ }^{6}$.

Conforme o Art. 202 da Constituição Federal de 1988, “o regime de previdência privada, de caráter complementar e organizado de forma autônoma em relação ao regime geral de previdência social, será facultativo, baseado na constituição de reservas que garantam o benefício

\footnotetext{
${ }^{5}$ Conforme Ramos (2005), em 10 de janeiro de 1835 surgiu o Montepio Geral de Economia dos Servidores do Estado (Mongeral), que se traduziu em uma entidade aberta de previdência sem fins lucrativos. Ainda conforme o autor, a Mongeral foi a primeira entidade no Brasil com objetivo de complementar a renda dos trabalhadores, quando em inatividade de trabalhos assalariados.

6 Tal regime se caracteriza pela "capitalização dos recursos advindos das contribuições dos participantes e empregadores, além da rentabilidade dos recursos investidos ao longo do tempo para constituição de reservas até a integralização do valor necessário para garantir o compromisso total dos pagamentos dos benefícios" (BRASIL, 2020a, n. p.).
} 
contratado [...]" (BRASIL, 1988). Diante disso, de acordo com Pinheiro (2007), o RPC possui caráter único privado, e é uma opção aos segurados que desejam receber valores maiores aos tetos previstos constitucionalmente. Já Rangel (2013) define a previdência complementar como uma instituição que visa o acúmulo de recursos financeiros, durante determinado período, que serão transformados em renda quando o indivíduo necessitar ser segurado ou se aposentar.

Por esse viés, para Lavinas e Araújo (2017), a previdência complementar preencheu uma lacuna existente na previdência social, visto as necessidades que os indivíduos não conseguem satisfazer, mediante os planos de instituição da seguridade social e devido à insatisfação previdenciária.

Ademais, destaca-se que a elaboração de políticas e fiscalização do RPC é realizada conforme o tipo de regime adotado, seja por entidades abertas ou fechadas. O regime administrado pelas Entidades Abertas, no qual a entrada e aquisição é individual, a fiscalização fica a cargo da Superintendência de Seguros Privados (SUSEP). Já no regime gerido pelas Entidades Fechadas, em que se concentram os fundos de pensão, quem exerce a fiscalização é a Superintendência Nacional de Previdência Complementar (Previc) (BRASIL, 2012a; BRASIL, 2020a).

\section{Entidade Aberta de Previdência Complementar}

As Entidades Abertas de Previdência Complementar (EAPC) são organizadas, exclusivamente, sob a forma de sociedade autônoma, ou seja, com fins lucrativos, e têm por objetivo instituir e operar planos de benefícios de caráter previdenciário concedidos em forma de renda continuada ou pagamento único, acessíveis a quaisquer pessoas físicas (BRASIL, 2001; BRASIL, 2020b).

A respeito dos planos abertos de previdência, Beltrão (2004) argumenta que:

[...] os planos abertos podem ter a adesão de qualquer pessoa, inclusive funcionários de uma empresa ou conglomerado que, por qualquer razão, prefira não ter um fundo de pensão próprio e, por isso, encaminha seus funcionários para um plano aberto. Não há nenhum impedimento legal para que uma empresa opte por um ou outro desenho. Todavia, essa situação não prevalece para pessoas físicas (BELTRÃO, 2004, p.3).

Portanto, os planos de previdência abertos são oferecidos por instituições financeiras, as quais são remuneradas pela cobrança de uma taxa de administração para gestão do portfólio do plano. Observa-se que tais planos são ofertados a qualquer cidadão que sinta a necessidade de adquirir o produto e é caracterizado como um investimento de longo prazo.

Os planos de previdência aberta são compostos por dois tipos de modalidades: o Plano Gerador de Benefício Livre (PGBL) e o Vida Gerador de Benefício Livre (VGBL). Ambos estão 
disponíveis ao investidor no momento da contratação e, após acúmulo de rendimentos por determinado período, tendem a proporcionar aos participantes uma renda futura, seja ela mensal ou pagamento único (SUSEP, 2006).

O PGBL é um plano de Previdência Complementar, no qual, “[...] as pessoas usufruem do diferimento fiscal previsto no modelo completo da declaração de ajuste anual do IRPF, e a alíquota do imposto de renda incidirá sobre o valor a ser resgatado ou recebido sob a forma de renda" (SUSEP, 2006, p.42). Sendo assim, ele possibilita abater do IRPF as contribuições realizadas anualmente até o máximo de $12 \%$ da renda bruta tributável. Ainda conforme SUSEP (2020), observa-se que as pessoas que possuem dependentes podem deduzir um percentual do valor do plano no imposto de renda. Nota-se, ainda, que há incidência do imposto de renda sobre o valor total acumulado.

Por outro lado, o VGBL é caracterizado como um seguro de pessoa, "[...] destinado à parcela de consumidores que não usufruem do benefício de diferimento do imposto de renda previsto no modelo completo da declaração de ajuste anual do IRPF” (SUSEP, 2006 p. 42). Sendo assim, segundo Schossler e Conto (2015), esse plano é indicado às pessoas que usam o modelo simplificado de declaração de imposto de renda, já que não é possível deduzir na declaração ou aos isentos de imposto de renda.

\section{Entidade Fechada de Previdência Complementar}

As Entidades Fechadas de Previdência Complementar (EFPC) são instituídas como fundações sem fins lucrativos e com a principal finalidade de estabelecer e coordenar os planos de benefícios previdenciários. São organizadas por entidades patronais ou de classe, isso é, as patrocinadoras e instituidoras. Esse tipo de produto financeiro está disponível a qualquer cidadão que possua vínculo empregatício com empresas, órgãos públicos, sindicatos e associações representativas, que possuam planos de previdência aos colaboradores (BRASIL; 2019b; BRASIL, 2020b).

Para que seja possível a atuação das EFPC, é necessário que sejam seguidas normas legais e que estas sejam fiscalizadas por órgãos competentes. Assim, a Previc é a autarquia do governo federal responsável pela autorização, acompanhamento, verificação e fiscalização das atividades das EFPC. Já o Conselho Nacional de Previdência Complementar (CNPC), é o órgão responsável pela regulamentação das atividades e ações das EFPC, enquanto o Conselho de Recursos da Previdência Complementar (CRPC) é o órgão colegiado de última instância recursal do segmento para os meios administrativos instituídos pela Previc (PREVIC, 2020a). 
Segundo o Art. 31 da Lei Complementar no 109 de 2001:

As entidades fechadas são aquelas acessíveis, na forma regulamentada pelo órgão regulador e fiscalizador, exclusivamente:

I - aos empregados de uma empresa ou grupo de empresas e aos servidores da União, dos Estados, do Distrito Federal e dos Municípios, entes denominados patrocinadores;

II - aos associados ou membros de pessoas jurídicas de caráter profissional, classista ou setorial, denominadas instituidoras (BRASIL, 2001).

As EFPC são estabelecidas por empresas, privadas ou estatais, e sua característica principal é administrar e operar benefícios previdenciários, sem possuir fins lucrativos. A criação dessas entidades está condicionada ao incentivo do patrocinador em disponibilizar aos seus colaboradores, associados ou servidores, planos de benefícios voltados a fins de aposentadoria (BRASIL, 2020b).

Basicamente existem três tipos de planos relativos às EFPC, quais sejam: os benefícios definidos (BD); os benefícios de contribuição definida (CD); e a contribuição variável (CV).

No BD, o valor do benefício que o contribuinte receberá é determinado no momento de adesão. Ademais, as contribuições podem variar, desde que o indivíduo atinja o valor estipulado inicialmente. Já na $\mathrm{CD}$, as contribuições são definidas pelo patrocinador e pelo membro colaborador, e o valor que será recebido variará conforme o montante, o prazo de contribuição e a rentabilidade. Por fim, a CV é um plano misto que combina as modalidades $\mathrm{BD}$ e $\mathrm{CD}$, em que o participante estabelece com quanto irá contribuir mensalmente, sendo que a patrocinadora contribui de forma paritária. O valor do benefício final será resultado do esforço de poupança (BRASIL, 2020b)

Esse tipo de plano administrado pelas EFPC possui o intuito de garantir uma renda a mais para complementação da aposentadoria, como também, para eventuais problemas com saúde, morte, doença, invalidez (BRASIL, 2020b). Sendo assim, é importante analisar bem os benefícios oferecidos pelas patrocinadoras para validar se é um investimento viável para o próprio indivíduo. Para isso, faz-se importante possuir conhecimentos sobre a educação financeira e previdenciária, as quais serão tratadas a seguir, pois são ferramentas que ajudam na tomada de decisão.

\section{Educação financeira e previdenciária}

Em uma ampla pesquisa realizada no Brasil, na qual se entrevistou homens e mulheres, todos acima de 18 anos, residentes nas capitais das 27 unidades federativas e de todas as classes sociais, concluiu que $59 \%$ da população não faz nenhuma preparação para a aposentadoria. $\mathrm{O}$ motivo alegado para tal situação se refere à falta de dinheiro no final do mês $(36 \%$ dos 
entrevistados). Outro dado interessante é que $35 \%$ dos entrevistados disseram que esperam se sustentar apenas com a aposentadoria a ser recebida do RGPS, enquanto outros $42 \%$ disseram que pretendem contar com algum outro recurso, principalmente previdência privada. Entretanto, 70\% dos entrevistados responderam que se sentiam muitos confiantes com relação aos seus respectivos preparos para a aposentadoria (BANCO CENTRAL DO BRASIL; SPC BRASIL; CNDL, 2019). Tais dados corroboram a importância de se tratar cuidadosamente sobre educação financeira e previdenciária no país.

Conforme Calado e Santos (2018, p. 8), “o planejamento bem-sucedido da aposentadoria exige a formação de expectativas sobre uma série de eventos no futuro, e integrá-los e traduzi-los em decisões econômicas é imperativo". Nesse entendimento, os referidos autores apontam que, portanto, o planejamento para a aposentadoria é um dos aspectos mais importantes da educação financeira.

De acordo com a Organização para a Cooperação e Desenvolvimento Econômico (OCDE), pode-se compreender a educação financeira como

[...] o processo pelo qual consumidores/investidores financeiros aprimoram sua compreensão sobre produtos, conceitos e riscos financeiros e, por meio de informação, instrução e/ou aconselhamento objetivo, desenvolvem as habilidades e a confiança para se tornarem mais conscientes de riscos e oportunidades financeiras, a fazer escolhas informadas, a saber onde buscar ajuda, e a tomar outras medidas efetivas para melhorar seu bem-estar financeiro (OCDE, 2005, p. $5)$.

Desse modo, a educação financeira exerce um papel importante, na medida em que possibilita o enriquecimento dos indivíduos com conhecimentos, ajudando-os a se desenvolverem nas tomadas de decisões e melhorarem suas finanças pessoais, além de os aproximarem dos produtos financeiros a disposição no mercado. Contudo, adquirir produtos ou serviços financeiros exige que os usuários possuam conhecimento que os possibilitem escolher, entre as várias opções ofertadas, a que gerará maior benefício e a um custo reduzido (PINHEIRO, 2007; SAVOIA, SAITO e SANTANA, 2007; HENRIQUES, 2010).

Consonante a esse ponto, há mais de uma década, a OCDE preconizou dois pontos específicos sobre a educação financeira para poupança de aposentadoria, quais sejam:

i) Para indivíduos em planos de previdência privada, deve ser promovido o fornecimento, por parte das instituições financeiras, de informação e educação financeira adequada para a gestão de sua poupança e renda da aposentadoria futura.

ii) No que diz respeito planos de previdência corporativos (para os quais devem ser fornecidas informações e educação de forma consistente referente aos planos), deve ser promovida a educação financeira e a conscientização dos empregados e ferramentas de política correspondentes, tanto para as contribuições definidas como para os planos de benefícios dos planos (OCDE, 2005, p. 7). 
Todavia, conforme destaca a OCDE (2013), é na população vulnerável economicamente que proporcionalmente se identificam, na maioria das vezes, limitações no conhecimento e compreensão de produtos e conceitos financeiros. Não obstante, tal população têm dificuldade em tomar decisões financeiras a longo prazo e selecionar produtos financeiros que atendam às suas necessidades. Assim, conforme a referida organização, "isso pode ter consequências negativas não apenas no futuro bem-estar financeiro das pessoas e das famílias, mas também na estabilidade a longo prazo dos sistemas financeiros e econômicos" (OCDE, 2013, p. 11). Tal situação é bem proxima da realidade brasileira. Dessa forma, segundo a PREVIC (2020b, p. 1), "a necessidade de educar o cidadão brasileiro para lidar com suas finanças determinou a instituição de uma estratégia conjunta do Estado e da sociedade".

Isto posto, por meio do Decreto 7.397, de 22 de dezembro de 2010, instituiu-se a Estratégia Nacional de Educação Financeira (ENEF), com intuito de fornecer informações e propor ações para ajudar a população a tomar decisões financeiras independentes e conscientes. A ENEF possui o objetivo de impulsionar a educação financeira e previdenciária no país, incentivando os indivíduos a tomar decisões conscientes sobre a gerência do seu dinheiro, além de cooperar para a eficácia e solidez dos mercados financeiros, de previdência, de capitalização e de seguros (CONEF, 2009; BRASIL, 2010; BCB, 2011).

Entre os assuntos previstos na ENEF, a educação previdenciária tem se tornado cada vez mais relevante, em que pese as alterações demográficas e sociais do país (PREVIC, 2020b). Assim, desde o ano de 2008, entidades públicas e privadas são incentivadas a desenvolverem programas de educação financeira e previdenciária ${ }^{7}$, com o propósito exclusivo de difundir o conhecimento, informar, conscientizar e auxiliar a sociedade para que seus integrantes estejam aptos à tomarem as melhores decisões financeiras ao longo de suas vidas (BRASIL, 2017b; ABRAPP, 2020; PREVIC, 2020b). Todavia, segundo Magalhães e Alves (2019), apesar de os respectivos programas apresentarem características vantajosas, ainda se nota uma enorme carência de informações previdenciárias em determinados setores da sociedade, vide exemplo da população residente na área rural, sendo necessária a intensificação de ações para mitigar tal lacuna.

De acordo com Dutra (2014), quando se adquirem produtos financeiros com retornos de longo prazo, em que a arrecadação de dinheiro é fundamental, como na previdência privada, há uma menor atração da população, já que os fundos investidos serão usufruídos apenas no futuro. Portanto, a educação financeira e a educação previdenciária são relevantes, pois auxiliam os

\footnotetext{
${ }^{7}$ Para mais detalhes, sugere-se consultar: ABRAPP (2014, 2020), Castelão (2012), Calado (2016), AEF-Brasil (2018) e Magalhães e Alves (2019).
} 
indivíduos no controle de gastos e ainda revelam a importância de se poupar recursos para o futuro (WISNIEWSKI, 2011).

Assim, na medida em que há o aprofundamento do conhecimento de educação financeira, inicia-se um processo de interligação com a educação previdenciária. Desse modo, para Pinheiro (2008) apud Calado e Santos (2018) a educação previdenciária pode ser compreendida como uma extensão da educação financeira, estando a importância da mesma concentrada não somente na formação de poupança a longo prazo, mas, também, na familiaridade dos termos adotados nas questões previdenciárias, pois muitos deles são considerados complexos pela maioria da população, o que reflete na baixa adesão ao produto. Matos (2012) corrobora esse argumento, indicando que simplificando a linguagem, poder-se-ia até mesmo contribuir para a eficiência da proteção previdenciária.

Segundo Conti (2014), há uma dificuldade da população em adquirir planos de previdência complementar, muito disso advindo do fato dos contratos serem de longo prazo e os indivíduos terem de contribuir ao longo da vida para virem a receber o benefício após vários anos. Com isso, é necessário deixar de utilizar esse recurso no presente, postergando-os para se beneficiarem no futuro. Porém, conforme Castelão (2012 p. 31), “a população brasileira pode ser avaliada como consumista, com pouca preocupação em relação à poupança financeira e pouco interesse pela fase pós-aposentadoria, considerando-se o pouco conhecimento sobre o produto previdência”. Diante disso, a educação financeira, e previdenciária, se tornam importantes, uma vez que auxiliam a população a tomar decisões pensando no seu bem-estar futuro.

\section{Metodologia}

Visando atender plenamente ao objetivo proposto no estudo, o procedimento metodológico centrou-se em uma abordagem quantitativa, a qual voltou-se ao modelo de pesquisa descritiva. Para tanto, foi realizado um levantamento a partir de dados primários. Assim, utilizou-se um questionário como o instrumental para que fosse possível coletar as informações.

Quanto à elaboração do questionário, compete salientar que ele foi fundamentado em estudos anteriores correlatos ao assunto, como por exemplo, os estudos de Amadeu (2009) e Vieira, Bataglia e Sereia (2011), os quais trataram sobre a influência da educação financeira nas decisões de consumo, investimentos e poupança para acadêmicos de graduação. Já Martins et al. (2014), realizou um estudo sobre as contribuições da previdência complementar fechada e seu benefício na vida dos trabalhadores. Além desses, Silva e Teodoro (2019) investigaram o perfil dos investidores de uma amostra de universitários em um município no estado de São Paulo. 
A partir dos estudos referidos, realizou-se uma seleção de informações, a qual possibilitou a elaboração do questionário da atual pesquisa. Assim sendo, destaca-se que o questionário foi composto por 34 questões de resolução fechadas. Em sua composição, procurou-se contemplar questões sobre o perfil dos respondentes, buscando evidenciar a idade, sexo, estado civil, existência de filhos, escolaridade, ocupação e renda. Também, almejou-se identificar se os indivíduos possuíam algum tipo de controle de gastos e, ainda, se conseguiam poupar algum valor mensal sobre as rendas recebidas. Já quanto às questões voltadas à aposentadoria, houve questionamentos gerais sobre a previdência social, procurando identificar se essa seria suficiente para um período pós-laboral e se os indivíduos de fato acreditam que os recursos de tal estão assegurados pelos regimes previdenciários.

Ainda, complementando a composição do questionário, elaborou-se questões especificamente voltadas à previdência complementar, visando investigar se os indivíduos possuem tais planos e, ainda, se avaliam que esse ou outros tipos de investimentos de longo prazo são viáveis e seguros para suas aposentadorias. Por último, destinou-se algumas perguntas para verificar a percepção dos entrevistados sobre aspectos pontuais da reforma previdenciária.

Para que a pesquisa fosse válida estatisticamente, procedeu-se a realização do cálculo amostral, visando, com isso, determinar o número mínimo de pessoas que deveriam responder ao questionário. Para tanto, segundo dados do IBGE (2019), considerou-se a estimativa populacional total da região Sudoeste do Paraná em 625.378 habitantes $^{8}$. Assim, com base nessa informação e adotando-se um erro amostral de 5\% e um nível de confiança de 95\%, obteve-se a estimativa de 383 questionários como amostra final.

O período de coleta dos dados foi entre os meses de julho e novembro de 2019. Os questionários foram disponibilizados à população por meios eletrônicos online, isso a fim de agilizar o procedimento, reduzir custos e, também, poder ampliar a população pesquisada na amostra.

\section{Resultados e discussões}

A presente pesquisa envolveu o Sudoeste do Paraná, tendo como foco a população da referida região. Após a distribuição online dos questionários, houve um total de 405 retornos de respostas, porém, por motivos diversos, três questionários não foram validados, obtendo-se, portanto, um total de 402 respostas, ou seja, uma quantidade de 5,2\% superior ao indicado.

\footnotetext{
${ }^{8}$ População estimada para os 42 municípios que compõem a região.
} 
A pesquisa envolveu participantes de $76 \%$ dos municípios da região ${ }^{9}$, representado, com isso, uma boa estratificação territorial. Cabe destacar, ainda, as participações significativas nos municípios de Francisco Beltrão (25,12\%), Pato Branco (22,88\%), Bom Sucesso do Sul $(12,44 \%)$, e Itapejara d'Oeste $(4,48 \%)$.

Diante das respostas obtidas, foi possível traçar o perfil geral dos entrevistados. Tais informações podem ser visualizadas a seguir na Tabela 1, a qual também identifica e separa o grupo de pessoas que possuíam plano de previdência complementar daquelas que não realizavam tal investimento.

Basicamente, observa-se na Tabela 1 que o grupo de respondentes foi formado por $54,73 \%$ de pessoas do sexo feminino e 45,02\% do sexo masculino. Com relação à faixa etária, a mais representativa é dos 18 aos 24 anos (42,29\%), seguido pela faixa dos 25 aos 34 anos (26,62\%), dos 35 aos 49 anos (16,67\%), seguida pela população com 50 anos ou mais $(7,46 \%)$ e, por fim, os indivíduos com idade inferior a 18 anos (6,97\%). No que se refere ao estado civil, 62,19\% responderam ser solteiros, $24,88 \%$ casados, $10,45 \%$ possui união estável e os demais, que são os viúvos e divorciados/separados, apresentaram um percentual de apenas 1,24\% cada. Do total dos entrevistados, 70,90\% relataram não possuir filhos, o que talvez se justifique pela faixa etária predominante dos respondentes e devido à maioria ser solteiro.

Quanto à escolaridade, houve uma tendência mais acentuada aos níveis educacionais mais elevados, pois 40,55\% disseram ter ensino superior incompleto, ensino superior completo foram $17,41 \%$ e pós-graduados $21,14 \%$. O fato de o questionário ter sido encaminhado online pode ter influência direta nesse resultado. Além disso, a maioria dos respondentes disseram estar empregados com carteira de trabalho assinada (48,26\%), e praticamente a mesma porcentagem respondeu que a renda mensal média se situa na faixa entre $\mathrm{R} \$ 998,01$ a $\mathrm{R} \$ 2.994,00$.

\footnotetext{
${ }^{9}$ Retornaram respostas do municípios de Ampére, Bom Sucesso do Sul, Capanema, Chopinzinho, Clevelândia, Coronel Vivida, Cruzeiro do Iguaçu, Dois Vizinhos, Enéas Marques, Flor da Serra, Francisco Beltrão, Itapejara d'Oeste, Manfrinópolis, Mariópolis, Marmeleiro, Nova Esperança do Sudoeste, Nova Prata do Iguaçu, Palmas, Pato Branco, Perola d'Oeste, Pinhal de São Bento, Planalto, Realeza, Renascença, Salgado Filho, Salto do Lontra, Santa Izabel do Oeste, Santo Antônio do Sudoeste, São João, Saudade do Iguaçu, Sulina e Verê.
} 
Tabela 1 - Perfil dos contribuintes e não contribuintes em previdência complementar - Sudoeste do Paraná - 2019

\begin{tabular}{|c|c|c|c|c|}
\hline & Perfil & $\begin{array}{c}\text { Não possui } \\
\text { previdência } \\
\text { complementar }\end{array}$ & $\begin{array}{c}\text { Possui } \\
\text { previdência } \\
\text { complementar }\end{array}$ & $\begin{array}{l}\text { Percentual } \\
\text { Acumulado }\end{array}$ \\
\hline \multirow{2}{*}{ Sexo } & Feminino & $48,26 \%$ & $6,72 \%$ & $54,98 \%$ \\
\hline & Masculino & $38,06 \%$ & $6,97 \%$ & $45,02 \%$ \\
\hline \multirow{6}{*}{ Renda } & Não possui renda & $9,70 \%$ & $0,75 \%$ & $10,45 \%$ \\
\hline & Menos de $\mathrm{R} \$ 998,00$ & $12,44 \%$ & $0,75 \%$ & $13,18 \%$ \\
\hline & De $\mathrm{R} \$ 998,01$ a $\mathrm{R} \$ 2.994,00$ & $42,79 \%$ & $5,97 \%$ & $48,76 \%$ \\
\hline & De $R \$ 2.994,01$ a $R \$ 5.988,00$ & $15,42 \%$ & $4,23 \%$ & $19,65 \%$ \\
\hline & De $R \$ 5.988,01$ a $R \$ 9.980,00$ & $4,73 \%$ & $1,00 \%$ & $5,72 \%$ \\
\hline & Mais de $\mathrm{R} \$ 9.980,01$ & $1,24 \%$ & $1,00 \%$ & $2,24 \%$ \\
\hline \multirow{5}{*}{ Faixa etária } & Menos de 18 anos & $6,22 \%$ & $0,75 \%$ & $6,97 \%$ \\
\hline & De 18 a 24 anos & $36,57 \%$ & $5,72 \%$ & $42,29 \%$ \\
\hline & De 25 a 34 anos & $23,63 \%$ & $2,99 \%$ & $26,62 \%$ \\
\hline & De 35 a 49 anos & $13,43 \%$ & $3,23 \%$ & $16,67 \%$ \\
\hline & Mais de 50 anos & $6,47 \%$ & $1,00 \%$ & $7,46 \%$ \\
\hline \multirow{7}{*}{ Escolaridade } & Ensino fundamental incomplets & $1,00 \%$ & $0,00 \%$ & $1,00 \%$ \\
\hline & Ensino fundamental completo & $1,49 \%$ & $0,00 \%$ & $1,49 \%$ \\
\hline & Ensino médio incompleto & $6,97 \%$ & $0,75 \%$ & $7,71 \%$ \\
\hline & Ensino médio completo & $9,70 \%$ & $1,00 \%$ & $10,70 \%$ \\
\hline & Ensino superior incompleto & $35,57 \%$ & $4,98 \%$ & $40,55 \%$ \\
\hline & Ensino superior completo & $13,68 \%$ & $3,73 \%$ & $17,41 \%$ \\
\hline & Pós-graduação & $17,91 \%$ & $3,23 \%$ & $21,14 \%$ \\
\hline \multirow{5}{*}{ Estado Civil } & Solteiro (a) & $54,48 \%$ & $7,71 \%$ & $62,19 \%$ \\
\hline & Casado (a) & $20,90 \%$ & $3,98 \%$ & $24,88 \%$ \\
\hline & União estável & $8,71 \%$ & $1,74 \%$ & $10,45 \%$ \\
\hline & Divorciado/Separado (a) & $1,24 \%$ & $0,00 \%$ & $1,24 \%$ \\
\hline & Viúvo (a) & $1,00 \%$ & $0,25 \%$ & $1,24 \%$ \\
\hline \multirow{2}{*}{ Possui filhos } & Sim & $23,63 \%$ & $5,47 \%$ & $29,10 \%$ \\
\hline & Não & $62,69 \%$ & $8,21 \%$ & $70,90 \%$ \\
\hline
\end{tabular}

Fonte: Elaborada pelos autores.

Ainda na Tabela 1, é possível identificar os investidores e não investidores em previdência complementar da população do sudoeste paranaense. Diante das respostas obtidas, identificou-se um maior percentual de pessoas que não contribuem para a previdência complementar, representando $86,32 \%$ do total. Desse saldo, a participação feminina compôs $48,26 \%$, enquanto o sexo masculino 38,06\%. Apenas $13,68 \%$ dos respondentes afirmaram possuir algum tipo de contribuição para a previdência complementar, sendo que desses, 6,72\% são pertencentes ao sexo feminino e 6,97\% ao masculino. Ao relacionar tais dados com os resultados do estudo de Constanzi et al. (2017), que tratou sobre os contribuintes da previdência privada no Brasil, verifica-se que os dados encontrados para o Sudoeste do Paraná, em certa medida, corroboram os resultados dos referidos autores, pois os referidos autores também demonstram que os homens são os maiores contribuintes em planos de previdência complementar $(58,2 \%)$. 
Ao observar a variável renda, verifica-se que houve uma maior presença dos participantes da previdência complementar para o grupo que compõe a faixa entre $\mathrm{R} \$ 998,01^{10}$ a $\mathrm{R} \$ 2.994,00$ (5,97\%), seguindo por aqueles que possuem faixa de renda entre $\mathrm{R} \$ 2,994,01$ a $\mathrm{R} \$ 5.998,00$ (4,23\%). Além disso, verifica-se que, dentre os entrevistados, a maioria afirma não conseguir poupar nenhum valor dos seus recursos mensais $(29,10 \%)$, e dentre os grupos que afirmam conseguir poupar algum recurso, estão aqueles situados, principalmente, entre as faixas salariais de $\mathrm{R} \$ 998,01$ a $\mathrm{R} \$ 2.994,00$, seguidos pelos que recebem entre a faixa $\mathrm{R} \$ 2.994,01$ até $\mathrm{R} \$$ 5.998,00. Sendo assim, verifica-se uma correlação positiva entre as pessoas que conseguem economizar uma quantidade maior de recursos por mês com aquelas que contribuem com a previdência complementar.

No que diz respeito às ocupações, nota-se uma maior participação de pessoas que possuem previdência complementar entre aqueles que trabalham com carteira de trabalho assinada $(7,71 \%)$, os servidores públicos $(1,74 \%)$ e empregadores $(1,00 \%)$. A explicação para o servidor público ser a segunda ocupação que mais apresentou participação de contribuintes para a previdência complementar pode residir no fato da implementação do Regime de Previdência Complementar dos servidores públicos federais ${ }^{11}$. Novamente, os resultados acima vão de encontro ao apresentado por Constanzi et al. (2017), os quais verificaram que os maiores percentuais dos contribuintes em previdência complementar no Brasil, por ocupação, são os empregados com carteira de trabalho assinada, trabalhadores por conta própria, funcionários públicos e os empregadores.

Seguindo a análise, do ponto de vista de faixa etária, observa-se, na Tabela 1, que os grupos que apresentam os maiores números de respondentes possuidores de previdência complementar foram: os que estão na faixa etária entre 18 a 24 anos (5,72\%), seguido pela faixa dos 35 a 49 anos $(3,23 \%)$ e aqueles entre a faixa de 25 a 34 anos (2,99\%). Segundo a escolaridade, os que mais contribuem com planos de previdência privados são os que possuem ensino superior incompleto $(4,98 \%)$, ensino superior completo $(3,73 \%)$ e pós-graduados $(3,23 \%)$. Sendo assim, diante dos dados, verifica-se que na região Sudoeste do Paraná, as pessoas jovens e com maiores níveis educacionais apresentam-se mais propensas a possuírem planos de previdência complementar.

Quanto ao estado civil e a existência de filhos, segundo a Tabela 1, verifica-se que 7,71\% dos contribuintes com previdência complementar são solteiros, 3,98\% casados e 1,74\% possuem união estável. Com relação à existência de filhos, 70,90\% dos participantes não possuem filhos,

\footnotetext{
${ }^{10}$ Em 2019, ano que foi distribuído o questionário, o valor do salário mínimo no Brasil era de R 998,00. Assim, optou-se por adotar esse valor para fins de comparação com os demais trabalhos realizados no país, e não o salário mínimo regional no estado do Paraná.

${ }^{11}$ Para mais detalhes consultar a Lei no 12.618, de 30 de abril de 2012 (BRASIL, 2012b).
} 
contra 29,10\% que possuem. Portanto, nota-se que os maiores contribuintes afirmam ser solteiros e não possuir dependentes, uma possível explicação para isso é o fato de não possuírem comprometimento da renda com despesas familiares.

Realizada a devida caracterização do perfil entre os aplicadores e não aplicadores em previdência complementar no Sudoeste do Paraná, buscou-se levantar algumas informações, relacionando o grau de percepção dos entrevistados quanto ao fato de possuírem um benefício de aposentadoria assegurado tanto pelo RGPS ou RPPS e, se na percepção deles, tal benefício será suficiente para manter a subsistência pessoal quando usufruir dele. Os resultados estão na Tabela 2.

Tabela 2 - Relação do grau de percepção dos entrevistados quanto ao fato de ter um benefício de aposentadoria assegurado e se tal benefício será suficiente para sua subsistência - Sudoeste do Paraná - 2019

\begin{tabular}{cccc}
\hline Seu benefício será suficiente & \multicolumn{2}{c}{ Sua aposentadoria está assegurada? } & \multirow{2}{*}{ Total } \\
\cline { 2 - 3 } $\begin{array}{c}\text { para manter sua subsistência } \\
\text { pessoal após período laboral? }\end{array}$ & Não & Sim & \\
\cline { 2 - 3 } & $57,96 \%$ & $12,94 \%$ & $70,90 \%$ \\
Não & $1,74 \%$ & $3,48 \%$ & $5,22 \%$ \\
Sim & $16,67 \%$ & $7,21 \%$ & $23,88 \%$ \\
\hline Não Sei & $\mathbf{7 6 , 3 7 \%}$ & $\mathbf{2 3 , 6 3 \%}$ & $\mathbf{1 0 0 \%}$ \\
\hline Total & & & \\
\hline
\end{tabular}

Fonte: Elaborada pelos autores.

Pelos resultados expostos na Tabela 2, nota-se que 76,37\% dos respondentes acreditam que sua aposentadoria não está assegurada, enquanto 23,63\% acreditam estar assegurados. Grande parte dos respondentes $(57,96 \%)$ afirma que sua aposentadoria não está assegurada e que o recurso recebido não será suficiente para manter a subsistência pessoal. No geral, para 70,90\% dos entrevistados a renda recebida não será suficiente para manter a sua subsistência pessoal após se aposentarem.

Diante do total da população que afirmou não acreditar que a aposentadoria está assegurada (76,37\%), as principais razões elencadas foram: fraudes na previdência $(22,64 \%)$, reforma na previdência $(14,43 \%)$, déficit na previdência $(13,18 \%)$, maior expectativa de vida $(3,98 \%)$ e redução da taxa de natalidade $(0,50 \%)$.

Ainda se questionou aos respondentes quanto ao planejamento sobre sua aposentadoria, com destaque para os seguintes resultados: $37,10 \%$ ainda não pensaram sobre o assunto; $22,4 \%$ pretendem receber aposentadoria apenas pelo RGPS; 15,9\% possuem outros tipos de investimento 
para assegurar a aposentadoria; e, por fim, 10,9\% disseram pensar em começar a investir em previdência complementar.

Após verificar a situação que os indivíduos estão perante suas aposentadorias, a Tabela 3, a seguir, apresenta a combinação de resultados entre indivíduos que possuem ou não previdência complementar, relacionando ao fato desses acreditarem se a renda recebida com a previdência será suficiente para manter a subsistência pessoal após se aposentarem.

Tabela 3 - Relação entre os indivíduos possuírem previdência complementar e se esses acreditam que renda recebida do benefício será suficiente para manter a subsistência pessoal na aposentadoria - Sudoeste do Paraná - 2019.

\begin{tabular}{cccc}
\hline $\begin{array}{c}\text { A renda do benefício será } \\
\text { suficiente para manter sua } \\
\text { subsistência? }\end{array}$ & \multicolumn{2}{c}{$\begin{array}{c}\text { Você possui previdência } \\
\text { complementar? }\end{array}$} & \multirow{2}{*}{ Total } \\
\cline { 2 - 3 } & Não & Sim & \\
\hline Não & $59,49 \%$ & $11,44 \%$ & $70,90 \%$ \\
Sim & $4,48 \%$ & 0,75 & $5,22 \%$ \\
Não Sei & $22,39 \%$ & $1,49 \%$ & $23,28 \%$ \\
\hline Total & $\mathbf{8 6 , 3 2 \%}$ & $\mathbf{1 3 , 6 8 \%}$ & $\mathbf{1 0 0 \%}$ \\
\hline
\end{tabular}

Fonte: Elaborada pelos autores.

Do total dos respondentes, conforme a Tabela 3, 86,32\% dos entrevistados dizem não possuir planos de previdência complementar, enquanto 13,68\% possuem. Ao questionar se a renda recebida pelo benefício previdenciário será suficiente para manter a subsistência pessoal, 70,90\% dos respondentes acreditam que não será suficiente e 23,28\% não souberam responder. Ademais, destaca-se o resultado que a maioria dos indivíduos $(59,49 \%)$ acredita que o benefício (recebido pelo RGPS ou RPPS) não será suficiente para manter sua subsistência. Todavia, nota-se nos resultados que, mesmo cientes de tal resultado incerto no futuro, ainda assim, poucas pessoas no Sudoeste do Paraná $(13,68 \%)$ se preocupam em dispor de um plano de previdência complementar.

Quanto aos 11,44\% dos entrevistados que disseram já possuir previdência complementar, procurou-se investigar as razões que os levaram a adquirirem tais planos, quais sejam: acreditar que o benefício não será suficiente para manter o padrão de vida atual $(38,16 \%)$; segurança para o futuro (34,58\%); incentivo fornecido pela empresa que trabalha $(14,55 \%)$; considerar uma maneira de poupar $(7,31 \%)$; e achar um bom investimento $(5,45 \%)$. Verifica-se, portanto, que na região, a população possuidora dos planos de previdência complementar se demonstra preocupada com a situação financeira e a garantia de uma renda no futuro. 
Ainda sobre os indivíduos possuidores da previdência complementar, apresentam-se na Tabela 4 as principais características dos planos previdenciários destes, como o tipo de plano, a modalidade escolhida, a contribuição mensal, o pagamento de taxas administrativas, a forma de resgate e qual o principal propósito para o valor que está investindo.

De acordo com os atributos dos planos de previdência complementar dos indivíduos que compuseram a amostra, houve uma participação equivalente entre aqueles que possuem planos de previdência aberta e os que têm planos de previdência fechada $(30,91 \%)$, sendo tais planos adquiridos em instituições financeiras ou por meio de empresas patrocinadoras. Uma parcela considerável dos respondentes $(38,18 \%)$ não sabia qual o plano adquirido, evidenciando que, supostamente, os indivíduos contratam esse produto sem possuírem conhecimentos básicos sobre suas características.

Tabela 4 - Características gerais dos planos de previdência complementar contratados na região Sudoeste do Paraná - 2019.

\begin{tabular}{|c|c|c|}
\hline Variável & Alternativa & Percentual \\
\hline \multirow{3}{*}{ Tipo do plano } & Planos de previdência abertos & $30,91 \%$ \\
\hline & Planos de previdência fechados & $30,91 \%$ \\
\hline & Não Sei & $38,18 \%$ \\
\hline \multirow{5}{*}{ Modalidade do plano } & Plano Gerador de Benefício Livre - PGBL & $36,36 \%$ \\
\hline & Vida Gerador de Benefício Livre - VGBL & $27,27 \%$ \\
\hline & Benefício Definido & $17,73 \%$ \\
\hline & Contribuição Definida & $14,55 \%$ \\
\hline & Contribuição Variável & $9,09 \%$ \\
\hline \multirow{6}{*}{ Contribuição mensal do plano } & Menos de $\mathrm{R} \$ 100,00$ & $43,64 \%$ \\
\hline & $\mathrm{R} \$ 100,01$ a $\mathrm{R} \$ 300,00$ & $41,82 \%$ \\
\hline & $\mathrm{R} \$ 300,01$ a $\mathrm{R} \$ 500,00$ & $5,45 \%$ \\
\hline & $\mathrm{R} \$ 500,01$ a $\mathrm{R} \$ 700,00$ & $3,64 \%$ \\
\hline & $\mathrm{R} \$ 700,01$ a $\mathrm{R} \$ 900,00$ & $1,82 \%$ \\
\hline & Acima de $\mathrm{R} \$ 900,01$ & $3,64 \%$ \\
\hline \multirow{6}{*}{ Pagamento de taxa administrativa } & Não sei & $58,18 \%$ \\
\hline & De $0,1 \%$ a $1 \%$ ao ano & $20,00 \%$ \\
\hline & De $1,1 \%$ a $2 \%$ ao ano & $14,55 \%$ \\
\hline & De $3,1 \%$ a $4 \%$ ao ano & $3,64 \%$ \\
\hline & De $2,1 \%$ a $3 \%$ ao ano & $1,82 \%$ \\
\hline & Mais de $3 \%$ & $1,82 \%$ \\
\hline \multirow{4}{*}{ Forma de Resgate } & Resgate único & $29,09 \%$ \\
\hline & Renda mensal com prazo determinado & $25,45 \%$ \\
\hline & Renda mensal com prazo indeterminado & $18,18 \%$ \\
\hline & Não sei & $27,27 \%$ \\
\hline $\begin{array}{l}\text { Propósito para o dinheiro que vai } \\
\text { receber da } \\
\text { Complementar }\end{array}$ & $\begin{array}{l}\text { Ter um recurso extra para precaução, como } \\
\text { eventuais gastos com saúde } \\
\text { Investir o recurso apenas para minha própria } \\
\text { subsistência e de minha família }\end{array}$ & $34,55 \%$ \\
\hline
\end{tabular}




$\begin{array}{lc}\text { Utilizar esse valor para lazer } & 9,09 \% \\ \text { Investir em imóveis } & 7,27 \% \\ \text { Viajar } & 7,27 \% \\ \text { Adquirir bens } & 5,45 \% \\ \text { Abrir um negócio } & 1,82 \% \\ \text { Possui vários propósitos para o dinheiro } & 1,82 \% \\ \text { Não sei } & 18,18 \%\end{array}$

Fonte: Elaborada pelos autores.

Ainda de acordo com a Tabela 4, quanto à modalidade do plano, destaca-se, principalmente, o Plano Gerador de Benefício Livre (36,36\%) e Vida Gerador de Benefício Livre (27,27\%). Já nos planos relativos às entidades fechadas, o destaque ficou para o de benefício definido $(17,73 \%)^{12}$. Com relação à contribuição mensal, a parcela maior dos respondentes contribui com valores de até R \$ 100,00 (43,64\%), seguido por aqueles que possuem contribuições mensais entre R \$ 101,00 a RS 300,00 (41,82\%). Os valores das contribuições, provavelmente, estão diretamente relacionados ao fato de grande parte dos indivíduos da amostra receberem salários intermediários, conforme apresentado na Tabela 1.

Com relação às taxas administrativas dos planos, observou-se que 58,18\% não possuíam conhecimento sobre o valor pago, enquanto outros $34,55 \%$ disseram pagar até $2 \%$ de taxas anual. Todavia, preocupa o fato de alguns respondentes alegarem que pagam mais de $3 \%$ ao ano de taxas, sendo que alguns até relataram pagamentos superiores a $5 \%$ ao ano, o que é bem elevado, conforme a taxa média praticada pelo mercado ${ }^{13}$. Esse percentual de indivíduos que não possuem conhecimentos sobre a taxa administrativa paga e sobre a forma de recebimento do investimento, demostram claramente uma lacuna no processo de educação previdenciária, uma vez que eles podem estar fazendo aquisições de produtos sem verificar quais os valores cobrados pelas instituições ou fundos para cuidar dos seus recursos, ou mesmo analisando ou comparando com as demais possibilidades ofertadas no mercado financeiro.

Além do montante a ser resgatado, talvez a segunda maior preocupação de quem aplica seus recursos em um plano de previdência complementar seja quando irá reaver o montante investido e de que forma se dará tal resgate. Conforme Tabela 4 , no que diz respeito à forma de resgate, houve entre os respondentes uma predominância pelo resgate único $(29,09 \%)$, seguido por aqueles que não têm conhecimento do resgate escolhido (27,27\%), aqueles que preferiram resgates

\footnotetext{
12 Conforme dados do Brasil (2019a, p. 4), no país, o fluxo de contribuições das EAPC está majoritariamente concentrado em VGBL (cerca de 89\%), enquanto o PGBL é responsável por cerca de 8\%. Nas EFPC, os planos BD representam cerca de $46 \%$ das contribuições, seguido pelo plano de CV (31\%) e os planos CD (23\%).

${ }^{13}$ Segundo Brasil (2019a), em dezembro de 2019, em média, a taxa de administração praticada era de $0,36 \%$ a.a. e a taxa de carregamento de $2,91 \%$ a.a.
} 
mensais com prazo determinado $(25,45 \%)$ e, ainda, resgates mensais com prazo indeterminado $(18,18 \%)$.

Referente ao propósito de uso para o dinheiro que receberá, ainda como exposto na Tabela 4, a maior parte dos entrevistados diz contribuir para ter recurso extra para precauções, como eventuais problemas de saúde (34,55\%), seguido por aqueles que não sabem ainda o que fazer com o dinheiro $(18,18 \%)$, aqueles que realizam o investimento para ter um recurso apenas para a própria subsistência e de sua família $(14,55 \%)$, os que desejam utilizar para lazer $(9,09 \%)$, os que pretendem investir o valor em imóveis $(7,27 \%)$, aqueles que pretendem realizar viagens $(7,27 \%)$ e, ainda, os que pretendem adquirir bens e os que possuem vários propósitos para o valor investido.

Após conhecer sobre essas características gerais dos planos optados pelos indivíduos na aquisição de previdência complementar, na sequência, a Tabela 5 expõe algumas percepções sobre a relação entre a aposentadoria dos regimes básicos (RGPS e RPPS) com a previdência complementar. Procura-se, assim, verificar na opinião dos respondentes qual das fontes gerará maior impacto em suas rendas futuras e, também, sobre qual é mais confiável para o recebimento do benefício.

Conforme a Tabela 5, para 56,36\% dos entrevistados os valores obtidos pelos regimes básicos serão menores que o proveniente da previdência complementar, 23,64\% julgam que serão iguais, enquanto $20 \%$ acham que os regimes básicos proporcionarão um montante superior ao da previdência complementar. Com relação à confiança das aplicações, 60\% julgam a previdência complementar mais segura, outros $29,09 \%$ dizem que ambos são, ao passo que apenas 1,82\% dos respondentes acreditam que os regimes básicos são mais seguros, ou seja, garantirão o recebimento do benefício quando o assegurado estiver apto para tal.

Tabela 5 - Relações entre a aposentadoria dos regimes básicos e a previdência complementar Sudoeste do Paraná - 2019

Dentre os benefícios dos regimes básicos e da Previdência Complementar, qual você acredita que irá gerar um impacto maior na sua renda?

Os valores obtidos pelos regimes básicos serão menores que Previdência Complementar

Percentual

Os valores obtidos pelos regimes básicos serão iguais ao da Previdência Complementar

$56,36 \%$

Os valores obtidos pelos regimes básicos serão maiores que o da Previdência Complementar

$23,64 \%$

Dentre os benefícios dos regimes básicos e da Previdência Complementar, qual você julga ser mais confiável para receber o seu benefício?

A previdência complementar é mais segura que os regimes básicos

$60,00 \%$

Ambos os casos possuem o mesmo nível de segurança

$29,09 \%$

Os regimes básicos são mais seguros que a Previdência Complementar

$1,82 \%$

Não sei

$9,09 \%$

Fonte: Elaborada pelos autores. 
A pesquisa ainda abordou um outro tema sensível à opinião das pessoas, qual seja, a reforma da previdência. Para isso, buscou-se analisar se para os entrevistados a reforma da previdência incentiva as aplicações em previdência complementar e, ainda, verificar a percepção deles se a proposta de mudança do regime de repartição simples para o regime de capitalização seria benéfica à aposentadoria. Os resultados estão na Tabela 6, a seguir.

Ao questionar se após a Reforma da Previdência a aposentadoria estaria assegurada, conforme a Tabela 6, o maior número de pessoas acredita que seria necessário algum investimento alternativo (37,06\%), seguido por aqueles que não sabiam $(33,83 \%)$ e, ainda, aqueles que julgam ser necessários investimentos em previdência complementar (16,92\%). Assim, verifica-se um percentual acentuado de indivíduos que destacam a importância de investimentos complementares para a renda, o que é de grande importância e mostra que, possivelmente, tais indivíduos preocupam-se com seu futuro em um momento pós-laboral.

Tabela 6 - Percepção sobre a Reforma da Previdência Social - Sudoeste do Paraná - 2019

\section{Com a aprovação da reforma da previdência, a aposentadoria estaria assegurada}

Acredito que após a Reforma da Previdência será necessário realizar algum investimento alternativo

Acredito que após a Reforma da Previdência será necessário investir em uma Previdência Complementar

Acredito que as mudanças na Previdência irão assegurar minha aposentadoria

Já estou aposentado

Não sei
Percentual

$37,06 \%$

$16,92 \%$

$10,95 \%$

$1,24 \%$

$33,83 \%$

Uma mudança do regime de repartição simples para o regime de capitalização é benéfica a aposentadoria

Acredito que o regime de capitalização é benéfico à aposentadoria $23,13 \%$

Acredito que irá prejudicar minha aposentadoria

Acredito que tanto no regime simples como no regime de capitalização minha aposentadoria está assegurada, já que em ambos os regimes eu irei realizar contribuições.

Fonte: Elaborada pelos autores.

Ainda segundo a Tabela 6, com relação a uma possível alteração do sistema de repartição simples para o de capitalização, 42,79\% não sabem se a transição seria benéfica, enquanto 23,13\% acreditam ser benéfica e $21,39 \%$ afirmavam ser prejudicial. Cabe destacar que esse ponto 
específico sobre a repartição foi retirado da Reforma da Previdência aprovada em 2019, porém, grupos políticos, incluindo aqui representantes do governo federal, ainda são favoráveis a tal proposta, sendo que a mesma poderá voltar à pauta de discussão em momento não muito distante no futuro.

Por fim, faz-se oportuno analisar a relação entre conhecimento em educação previdenciária da população no Sudoeste do Paraná, com o fato de os indivíduos possuírem, ou não, previdência complementar. Para tanto, o questionário trazia perguntas nas quais os participantes deveriam fazer uma autoavaliação quanto aos seus níveis de conhecimentos de educação previdenciária. $\mathrm{O}$ resultado do cruzamento dessas informações está apresentado na Tabela 7.

Assim, conforme a Tabela 7, o resultado nitidamente indica haver uma relação inversamente proporcional entre o nível de educação previdenciária e a aquisição de um plano de previdência complementar. Isso fica explícito ao constatar que entre os que se autoavaliam como péssimo o seu nível de conhecimento em educação previdenciária, 96,43\% não aplicam em previdência complementar. Por outro lado, dentre o grupo que se autoavalia como detentores de um excelente conhecimento em educação previdenciária, $23,53 \%$ do total indicaram ser aplicadores em previdência complementar. Tal resultado sugere que, uma vez se aprendendo mais sobre educação previdenciária, o indivíduo se torna mais propenso a possuir previdência complementar.

Tabela 7 - Relação entre os níveis de autoavaliação em educação previdenciária e os investimentos em previdência complementar - Sudoeste do Paraná - 2019

\begin{tabular}{cccc}
\hline $\begin{array}{c}\text { Conhecimentos } \\
\text { sobre educação } \\
\text { previdenciária }\end{array}$ & \multicolumn{2}{c}{$\begin{array}{c}\text { Possui planos de previdência } \\
\text { complementar? }\end{array}$} & Total \\
\cline { 2 - 3 } & Não & Sim & \\
\hline Péssimo & $96,43 \%$ & $3,57 \%$ & $100,00 \%$ \\
Ruim & $95,16 \%$ & $4,84 \%$ & $100,00 \%$ \\
Regular & $92,44 \%$ & $7,56 \%$ & $100,00 \%$ \\
Bom & $80,37 \%$ & $19,63 \%$ & $100,00 \%$ \\
Excelente & $76,47 \%$ & $23,53 \%$ & $100,00 \%$ \\
\hline
\end{tabular}

Fonte: Elaborada pelos autores.

Também se realizou uma análise sobre as razões que levam os indivíduos a possuir previdência complementar e se quem possui educação previdenciária está mais propenso a planos previdenciários. Assim, houve um grande quadro de respostas que indicou que as pessoas com 
maiores níveis educacionais tendem a possuir previdência complementar, porém esses mesmos afirmam, principalmente, que não possuem condições financeiras para aquisição de planos previdenciários $(19,88 \%)$ e que possuem falta de informação sobre o produto $(17,87 \%)$.

A partir de tais dados, buscou-se relacionar o nível de educação previdenciária e as razões que levam os indivíduos a não investirem em previdência complementar. Entre os respondentes que alegam possuir nível regular de educação previdenciária, não possuem previdência complementar por falta de informações sobre o produto $(10,09 \%)$, por não possuir condições financeiras para tal $(9,8 \%)$, ou por acreditar que é muito jovem para pensar na aposentadoria $(9,22 \%)$.

Já os que dizem ter nível de educação previdenciária bom, não possuem previdência complementar, principalmente, por não possuírem condições financeiras para tal $(4,9 \%)$, seguido por aqueles que realizam outro tipo de investimento que julga mais viável $(4,61 \%)$ e, ainda, por falta de informação sobre o produto $(3,46 \%)$.

Portanto, a partir de tal análise pressupõe-se que possuir educação previdenciária não necessariamente é condição suficiente para realizar investimentos em previdência complementar. Tal conclusão decorre, primeiramente, porque o maior número de respondentes afirma possuir educação previdenciária, mas não possuir investimentos em previdência complementar. Segundo, porque grande percentual dos respondentes afirma deter conhecimento nas relações previdenciárias, mas não possuem condições financeiras para investir em previdência complementar. E o terceiro ponto considerável da análise é a falta de informações sobre o produto que, em tese, é reflexo da falha no processo de construção e aprimoramento dos conhecimentos acerca dos assuntos previdenciários. No entanto, no âmbito financeiro, o impacto disso não é notável no presente, sendo, infelizmente, sentido somente quando o indivíduo já estiver próximo de se aposentar, ou mesmo já aposentado, e verificar que sua renda será menor do que a que ele obtinha quando estava economicamente ativo no mercado.

\section{Considerações finais}

Diante da situação atual do sistema previdenciário brasileiro, tem-se a necessidade de se pensar em métodos financeiros alternativos que possam ser contratados ainda quando as pessoas se encontram no período economicamente ativo, visando a complementação da renda em um período pós-laboral. Em que pese as incertezas futuras, os indivíduos que realizam algum tipo de investimento visando a complementação de suas rendas tendem a possuírem maior tranquilidade financeira, garantindo, assim, uma aposentadoria mais estável, pois tal atitude poderá gerar uma segurança maior no momento de inatividade laboral. $\mathrm{O}$ fato relatado é corroborado na percepção 
da amostra deste estudo, uma vez que a maioria acredita que, no futuro, os benefícios provenientes da previdência complementar serão maiores que os dos regimes básicos.

Assim, esse artigo teve por objetivo analisar o comportamento dos investimentos em previdência complementar da população residente na mesorregião Sudoeste do Paraná. Com base nos resultados obtidos por meio da amostra populacional pesquisada, concluiu-se que apenas ter educação previdenciária não é condição suficiente que possibilite as pessoas aplicarem em previdência complementar. Ademais, ressalta-se o ponto que a maioria dos entrevistados não realizavam tal investimento e, dentre as razões para tal, destacaram-se: não possuir condições financeiras, falta de informação sobre o produto e, ainda, considerar-se jovem para pensar na aposentadoria. Outro resultado preocupante e que deve ser ressaltado foi que $29,10 \%$ dos entrevistados afirmaram que não conseguiam poupar nenhum valor dos seus recursos recebidos mensalmente.

Já entre os entrevistados que aplicam em previdência complementar, muitos não conheciam algumas informações básicas, como o tipo de plano contratado, valor pago de taxas e forma de resgate do dinheiro. Todavia, surpreendeu o resultado que a maioria dos aplicadores na previdência complementar na região estão situados na faixa de renda até três salários mínimos. Logo, a explicação para isso pode residir na oferta de planos previdenciários patrocinados pelas empresas empregadoras.

Sendo assim, diante da atual situação e de acordo com os resultados obtidos, faz-se necessário repensar alternativas para que a população tome consciência da necessidade e importância de não depender dos planos previdenciários públicos como única fonte de renda. Desse modo, sugere-se a intensificação na educação previdenciária e financeira da população, visto que muitos ainda não possuem conhecimentos básicos sobre tais assuntos. Ampliando o conhecimento, é possível buscar e selecionar as melhores alternativas de investimentos e, assim, os indivíduos poderão, provavelmente, usufruir de um futuro melhor no período pós-laboral.

\section{Referências}

Associação Brasileira das Entidades Fechadas de Previdência Complementar (ABRAPP). Guia para modelagem de programas de educação financeira e previdenciária. 2014. Disponível em: http://www.abrapp.org.br/GuiasManuais/Guia_modelagem.pdf. Acesso em:

Educação Previdenciária e Financeira. 2020. Disponível em: http://www.abrapp.org.br/Paginas/Educacao-previcendiaria-e-financeira.aspx. Acesso em: 01. jul. 2020. 
AMADEU, J. R. A educação financeira e sua influência nas decisões de consumo e investimento: proposta de inserção da disciplina na matrícula curricular. 2009. f. 92 Dissertação (Mestrado em educação), Universidade do Oeste Paulista - UNOESTE, São Paulo, 2009.

ASSOCIAÇÃO DE EDUCAÇÃO FINANCEIRA DO BRASIL (AEF-BRASIL). Mapeamento de iniciativas de Educação financeira. 2018. Disponível em: https://www.vidaedinheiro.gov.br/wp-content/uploads/2018/05/Mapeamento_2018.pdf. Acesso em: 01 jul. 2020.

BANCO CENTRAL DO BRASIL. Brasil: implementando a estratégia nacional de educação financeira. $2011 . \quad$ Disponível em: https://www.bcb.gov.br/pre/pef/port/Estrategia_Nacional_Educacao_Financeira_ENEF.pdf.

Acesso em: 07 jul. 2020.

BANCO CENTRAL DO BRASIL; SPC BRASIL; CNDL. Preparo do brasileiro para o futuro e imprevistos. 2019. Disponível em: https://bit.ly/3jqt3cY. Acesso em: 01 jul. 2020.

BELTRÃO, K. I. et al. Análise da Estrutura da Previdência Privada Brasileira: Evolução do Aparato Legal". Texto para discussão, IPEA, 2004. Disponível em: https://www.ipea.gov.br/portal/index.php?option=com_content\&view=article\&id=4241_Acesso em: 15 mai. 2020.

BRASIL. Lei 6.435, de 15 de julho de 1977. Dispõe sobre as entidades de previdência privada. Brasília, 1977. Disponível em: http://www.planalto.gov.br/ccivil_03/LEIS/L6435.htm. Acesso em: 10 jul. 2019.

Decreto n. 81.240, de 20 de janeiro de 1978. Regulamenta as disposições da Lei $\mathbf{n}^{\mathbf{0}}$ 6.435, de 15 de julho de 1978, relativas às entidades fechadas de previdência privada. Brasília, $1978 . \quad$ Disponível em: http://www.planalto.gov.br/ccivil_03/decreto/Antigos/D81240.htm. Acesso em: 10 jul. 2019.

Constituição da República Federativa do Brasil de 1988. Brasília, DF: Presidência da República, $1988 . \quad$ Disponível em: http://www.planalto.gov.br/ccivil_03/constituicao/constituicao.htm. Acesso em: 10 jul. 2019.

Emenda constitucional n. 18, de 05 de fevereiro de 1998. Brasília, 1998. Disponível em: http://www.planalto.gov.br/ccivil_03/Constituicao/Emendas/Emc/emc18.htm. Acesso em: 10 jul. 2019.

Lei complementar $n^{\circ} 109$, de 29 de maio de 2001. Dispõe sobre o Regime de Previdência Complementar dá outras providencias. Brasília, 2001. Disponível em: http://www.planalto.gov.br/ccivil_03/leis/LCP/Lcp109.htm. Acesso em: 15 fev. 2020.

Decreto n. 7.397, de 22 de dezembro de 2010. Institui a Estratégia Nacional de Educação Financeira - ENEF, dispõe sobre a sua gestão e dá outras providências. 2010. Disponível em: http://www.planalto.gov.br/ccivil_03/_Ato2007-2010/2010/Decreto/D7397.htm. Acesso em: 07 jul. 2020.

Ministério da Previdência Social (MPS). Guia de previdência complementar para Estados, Distrito Federal e Municípios. Brasília, 2012a. Disponível em: 
http://sa.previdencia.gov.br/site/arquivos/office/1_121204-113523-300.pdf. Acesso em: 02 fev. 2020

Lei $\mathrm{n}^{\circ} 12.618$, de 30 de abril de 2012. Institui o regime de previdência complementar para os servidores públicos federais titulares de cargo efetivo, inclusive os membros dos órgãos que menciona. 2012b. Disponível em: http://www.planalto.gov.br/ccivil_03/_ato2011-2014/2012/lei/112618.htm\#art33. Acesso em: 01 set. 2020.

Ministério da Previdência Social. Anuário Estatístico da Previdência Social. 2017a. Disponível em: http://sa.previdencia.gov.br/site/2019/04/AEPS-2017-abril.pdf. Acesso em: 28 set. 2019. Acesso em: 10 jul. 2019.

Ministério da Economia. Programa de Educação Previdenciária - PEP. 2017b. Disponível em: https://www.inss.gov.br/acesso-a-informacao/programa-de-educacaoprevidenciaria/. Acesso em: 29 jul. 2020

Ministério da Fazenda. Envelhecimento da população e seguridade social. Brasília: MF; SPREV, 2018. Disponível em: https://www.gov.br/previdencia/ptbr/images/2018/06/colprev37.pdf. Acesso em: 15 mai. 2020.

Ministério da Economia. Relatório Gerencial de Previdência Complementar. Brasília, 2019a. Disponível em: https://www.gov.br/previdencia/pt-br/acesso-ainformacao/dados-abertos/previdencia-complementar/surpc_relger_19.12b.pdf. Acesso em: 17 ago. 2020

Ministério da Economia. Boletim estatístico da Previdência Social. Brasília, dez. 2019b. Disponível em: https://www.gov.br/previdencia/pt-br/acesso-a-informacao/dadosabertos/arquivos/beps122019_trab_final.pdf. Acesso em: 21 mai. 2020.

. Ministério da Economia. Previdência Complementar: Conceitos. 2020a. Disponível em: https://www.gov.br/previdencia/pt-br/assuntos/previdencia-complementar/maisinformacoes/conceitos Acesso em: 15 fev. 2020.

Ministério da Economia. O que é Previdência Complementar. $2020 \mathrm{~b}$. Disponível em: https://www.gov.br/previdencia/pt-br/assuntos/previdencia-complementar/maisinformacoes/o-que-previdncia-complementar. Acesso em: 15 fev. 2020.

CALADO, L. R; SANTOS, D. C. Educação financeira e planejamento para a aposentadoria: um estudo com alunos de pós-graduação. Revista Práticas em contabilidade e gestão, v.6, n. 2, p.127, dez. 2018.

CALADO. L. R. Novas Estratégias de Educação Financeira que Possam ser Adaptadas e Implementadas no Brasil à Luz do Levantamento das Iniciativas Europeias. 2016. Disponível em: http://www.sectordialogues.org/sites/default/files/estudo_2__novas_estrategias_de_educacao_financeira___luiz_roberto_calado_0.pdf. Acesso em: 01 jul. 2020

CASTELÃO, S. R. A eficácia das ações de educação previdenciária como ferramenta para melhorar o entendimento do produto previdência privada. 2012. Dissertação (Mestrado em gestão empresarial) Escola Brasileira de Administração Pública. Rio de Janeiro, 2012. 
COMITÊ NACIONAL DE EDUCAÇÃO FINANCEIRA (CONEF). Estratégia Nacional de Educação Financeira. Brasília, 2009. Disponível em: https://www.vidaedinheiro.gov.br/wpcontent/uploads/2017/08/Plano-Diretor-ENEF-Estrategia-Nacional-de-Educacao-Financeira.pdf. Acesso em: 07 jul. 2020.

CONSTANZI, R. N. et al. Perfil dos contribuintes em previdência complementar. Nota técnica no 43, IPEA, 2017. Disponível em: http://repositorio.ipea.gov.br/handle/11058/8571. Acesso em 01 set. 2020 .

CONSTANZI, R. N. Breve análise da nova projeção da população do IBGE e seus impactos previdenciários. Diretoria de Estudos e Políticas Sociais. Dez 2018. Disponível em: http://www.ipea.gov.br/portal/images/stories/PDFs/nota_tecnica/1801207_nt_51_disoc_breve_a nalise_nova_projecao_populacao_ibge_impactos_previdenciarios.pdf. Acesso em: 01 set. 2019. Acesso em: 25 set. 2020.

CONTI, B. Os fundos brasileiros de previdência complementar: segmentações analíticas e estudos preliminares sobre a alocação de seus recursos. Texto para discussão, IPEA, 2014. Disponível em: http://repositorio.ipea.gov.br/bitstream/11058/8783/1/Os\%20Fundos\%20brasileiros.pdf. Acesso em: 05 jul. 2020.

DUTRA, A. C. Educação como base para um futuro financeiro saudável. 2014. Disponível em: http://www.administradores.com.br/mobile/artigos/economia-e-financas/educacao-comobase-para-um-futuro-financeiro-saudavel/80651/. Acesso em: 07 jul. 2020.

HENRIQUES, S. C. M. Aspectos da literacia financeira dos portugueses: um estudo empírico. 2010. Dissertação (Mestrado em contabilidade e auditoria). Universidade de Aveiro. Portugal 2010.

INSTITUTO BRASILEIRO DE GEOGRAFIA E ESTATÍSTICA (IBGE). Tendências demográficas: Uma análise da população com base nos resultados dos censos demográficos 1940 e 2000. Rio de Janeiro, 2007. Disponível em: https://biblioteca.ibge.gov.br/visualizacao/livros/liv34956.pdf. Acesso em: 15 fev. 2020.

Tábua completa de mortalidade para o Brasil. Rio de Janeiro, 2018. Disponível em: https://biblioteca.ibge.gov.br/visualizacao/periodicos/3097/tcmb_2017.pdf. Acesso em: 15 fev. 2020.

Estimativas da população residente para os municípios e para as unidades da federação com data de referência em $1^{\mathbf{0}}$ de julho de 2019. 2019. Disponível em: https://www.ibge.gov.br/estatisticas/sociais/populacao/9103-estimativasdepopulacao.html?=\&t=resultados. Acesso em: 5 de agosto de 2019.

INSTITUTO PARANAENSE DE DESENVOLVIMENTO ECONÔMICA E SOCIAL (IPARDES). Os vários Paranás: As especialidades socioeconômicas-institucionais no período 2003-2015. Curitiba, 2017. Disponível em: http://www.ipardes.pr.gov.br/Pagina/Edicao-2017. Acesso em: 17 jun. 2019

LAVINAS, L.; ARAUJO, E. Reforma da previdência e regime complementar. Revista de Economia Política, São Paulo, v. 37, n. 3, p. 615-635, jul./set. 2017. 
LUSARDI, A.; MITCHELL, O. S. Financial Literacy and Retirement Preparedness: Evidence and Implications for Financial Education. Revista Business Economics, v. 42, n. 1, p. 35-44, 2007.

MAGALHÃES, G. F.; ALVES, W. M. Cidadania e políticas públicas no contex to do programa de educação previdenciária - PEP. Revista do Direito Público, Londrina, v. 14, n. 1, p. 10-25, abr. 2019.

MARTINS, P. L. et al. Planos de Previdência Complementar Fechados: um Estudo sobre o Real Benefício deste Investimento na Vida do Trabalhador Moderno. In: XI Simpósio de Excelência em Gestão e Tecnologia - SEGET, Faculdades Dom Bosco, Resende, Rio de Janeiro. Anais [...] 2014. Disponível em: https://www.aedb.br/seget/arquivos/artigos14/20020334.pdf. Acesso em: 05 mai. 2020.

MATOS, M. A. Educação Previdenciária como Exercício de Cidadania. 2012. 110 f. Dissertação (Mestrado em Direito das Relações Sociais) - Pontifícia Universidade Católica de São Paulo, São Paulo, 2012.

ORGANIZAÇÃO PARA COOPERAÇÃO ECONÔMICA E DESENVOLVIMENTO (OCDE). Recommendation on Principles and Good Practices for Financial Education and Awareness. 2005. Disponível em: http://www.oecd.org/finance/financial-education/35108560.pdf. Acesso em: 02 jul. 2020.

Advancing National Strategies for Financial Education, 2013. Disponível em: https://www.oecd.org/finance/financial-education/G20_OECD_NSFinancialEducation.pdf. Acesso em: 05 jul. 2020.

PINHEIRO, R. P. A DEMOGRAFIA DOS FUNDOS DE PENSÃO. Brasília: MPAS, 2007.

RAMOS, M. C. O. Os planos de benefícios das entidades de previdência privada. São Paulo: LTr, 2005.

RANGEL, L. A. Criação da previdência complementar dos servidores federais: motivações e implicações na taxa de reposição das futuras aposentadorias. Texto para discussão, IPEA, 2013. Disponível em: http://repositorio.ipea.gov.br/bitstream/11058/1588/1/TD_1847.pdf. Acesso em: 01 jun. 2020.

SAVOIA, J. F. R.; SAITO, A.T.; SANTANA, S. A. Paradigmas da educação financeira no Brasil. Revista de Administração Pública, Rio de Janeiro, v. 41, n. 6, 2007.

SCHOSSLER, C. M.; CONTO, S. M. Previdência Privada Aberta: Um estudo sobre o produto no mercado de investimentos. Revista destaques acadêmicos, v. 7, n. 6, 2015.

SILVA, L. C. S.; TEODORO, L. F. Perfil dos investidores: o caso dos alunos universitários em Guarulhos, São Paulo. Revista Acadêmica Faculdade Progresso, São Paulo, v. 5, n. 1, 2019.

SUPERINTENDÊNCIA DE SEGUROS PRIVADOS (SUSEP). Guia de orientação e defesa do segurado: informe-se: proteja-se melhor: proteja-se melhor. 1. ed. Rio de Janeiro, jun. 2006. Disponível em: http://www.susep.gov.br/download/cartilha/cartilha_susep.pdf. Acesso em: 15 mai. 2020. 
Perguntas mais frequentes sobre planos por sobrevivência - pgbl e vgbl.

2020. Disponível em: http://www.susep.gov.br/setores-susep/seger/coate/perguntas-maisfrequentes-sobre-planos-por-sobrevivencia-pgbl-e-vgbl. Acesso em: 15 mai. 2020.

SUPERINTENDÊNCIA NACIONAL DE PREVIDÊNCIA COMPLEMENTAR (PREVIC). A Previc. 2020a. Disponível em: http://www.previc.gov.br/acesso-ainformacao/institucional/copy_of_a-previc-1. Acesso em: 21 mai. 2020.

Por que promover a educação financeira e previdenciária? $2020 \mathrm{~b}$. Disponível em: http://www.previc.gov.br/regulacao/educacao-previdenciaria/educacaofinanceira-e-previdenciaria/por-que-promover-a-educacao-financeira-e-previdenciaria. Acesso em: 05 jul. 2020.

VIEIRA, S. F. A.; BATAGLIA, R. T. M.; SEREIA, V. J. Educação Financeira e Decisões de Consumo, Investimento e Poupança: Uma análise dos alunos de uma Universidade Pública do Norte do Paraná. Revista de Administração da UNIMEP, São Paulo, v. 9, n. 3, p. 61-83, set./dez. 2011.

WISNIEWSKI, M. L. G. A importância da educação financeira na gestão das finanças pessoais: uma fase na popularização do mercado de capitais brasileiro. Revista Intersaberes, Curitiba, v.6, n.12, p. 155-172. 2011.

ZEMIACKI, J. Educação financeira: uma metodologia de pesquisa amostral para aferição de indicadores em fundos de pensão. 2015. Dissertação (Pós -Graduação em Economia) Universidade Federal do Rio Grande do Sul - UFRGS. Porto Alegre, 2015. 